\title{
IMMOBILIZATION OF HUMIC ACID ONTO CHITOSAN USING TOSYLATION METHOD WITH 1,4-BUTANEDIOL AS A SPACER ARM
}

\author{
Uripto Trisno Santoso ${ }^{1,2, *}$, Radna Nurmasari ${ }^{1}$, Dewi Umaningrum ${ }^{1}$, Sri Juari Santosa ${ }^{2}$, Bambang \\ Rusdiarso $^{2}$, and Dwi Siswanta ${ }^{2}$ \\ ${ }^{1}$ Department of Chemistry, Faculty of Mathematics and Natural Sciences, Universitas Lambung Mangkurat, \\ Jl. A. Yani Km 36 Banjarbaru, Kalimantan Selatan, Indonesia 70714 \\ ${ }^{2}$ Department of Chemistry, Faculty of Mathematics and Natural Sciences, Universitas Gadjah Mada, \\ Sekip Utara Bls 21, Yogyakarta, Indonesia 55281
}

Received November 3, 2011; Accepted December 27, 2011

\begin{abstract}
Immobilization of humic acid (HA) onto chitosan using tosylation method with 1,4-butanediol as a spacer arm has been evaluated. Chitosan was phthaloylated selectively using phthalic anhydride in dimethylformamide as solvent with addition of $5 \%$ water $(\mathrm{V} / \mathrm{V})$ as cosolvent prior to be tosylated. $\mathrm{N}$-phthaloyl-chitosan and HA were tosylated using tosyl chloride in excess and triethylamine as catalyst at temperature $<10^{\circ} \mathrm{C}$ for $12 \mathrm{~h}$. The 6-O-tosyl$\mathrm{N}$-phthaloyl-chitosan was reacted with 1,4-butanediol in order to obtain a spacer arm attached chitosan. The 6-Obutanol-N-phthaloyl-chitosan was activated by reacting with tosyl chloride. For evaluation on immobilization of HA on chitosan with and without spacer arm, 6-O-tosylbutane-N-phthaloyl-chitosan was reacted with HA and the 6-O-tosyl$N$-phthaloyl-chitosan was reacted with HA. The HA immobilized onto chitosan was characterized by XRD and FTIR spectrophotometric method. The result showed that HA can be immobilized covalently onto chitosan after attaching 1,4-butanediol as spacer arm onto 6-O-tosyl-N-phthaloyl-chitosan and activating the product with tosyl chloride, but HA cannot be reacted directly onto 6-O-tosyl-N-phthaloyl-chitosan.
\end{abstract}

Keywords: immobilization; humic acid; chitosan; tosylation; spacer arm

\section{ABSTRAK}

Imobilisasi asam humat (AH) pada kitosan menggunakan metode tosilasi dengan 1,4-butanadiol sebagai spacer arm telah dievaluasi. Kitosan terlebih dahulu diphthaloilasi secara selektif menggunakan anhidrida phthalat dalam dimetilformamida sebagai pelarut dan air 5\% (v/V) sebagai kopelarut sebelum ditosilasi. $N$-phthaloil-kitosan ditosilasi menggunakan tosil klorida berlebih dengan trietilamina sebagai katalis pada temperature $<10{ }^{\circ} \mathrm{C}$ selama 12 jam. 6-O-tosil-N-phthaloil-kitosan direaksikan dengan 1,4-butanadiol untuk memperoleh suatu kitosan yang mengikat spacer arm. 6-O-butanol-N-phthaloil-kitosan diaktivasi lagi dengan reaksi tosilasi. Imobilisasi AH pada kitosan dengan dan tanpa spacer arm berturut-turut dilakukan dengan cara mereaksikan $A H$ dengan 6-Otosilbutana-N-phthaloil-kitosan dan 6-O-tosil-N-phthaloil-kitosan. AH yang terimobilisasi pada kitosan dikarakterisasi dengnan metode spektrofotometri FTIR dan XRD. Hasil penelitian menunjukkan bahwa AH dapat diimobilisasi secara kovalen pada tosil-kitosan yang telah mengikat 1,4-butanadiol sebagai spacer arm, tetapi AH tidak dapat diimobilisasi secara langsung tosil-kitosan tanpa melalui spacer arm.

Kata Kunci: imobilisasi; asam humat; kitosan; tosilasi; spacer arm

\section{INTRODUCTION}

It is well known that humic substances have substantial ability to bind heavy metal ions [1-12]. The major binding sites are attributed to the oxygencontaining functional groups such as carboxylic and phenolic groups, which contribute to the total acidity of humic substances [13]. Infrared spectroscopy studies confirmed that carboxyl groups, or more precisely carboxylates, play a prominent role in the complexing of metal ions by humic and fulvic acids [14-18].

Humic acids (HA) are the component of humic substances that are insoluble at acidic condition $(\mathrm{pH}<2)$ but soluble at higher $\mathrm{pH}$ of medium [19]. The solubility of $\mathrm{HA}$ in aqueous media depends on the number of $-\mathrm{COOH}$ and $-\mathrm{OH}$ groups present in $\mathrm{HA}$ on a large scale and with increasing content of these groups the solubility increases. Because these groups are the most active sorption sites responsible for the formation

${ }^{*}$ Corresponding author. Tel/Fax : +62-5114773112

Email address : uriptots@yahoo.com

Uripto Trisno Santoso et al. 
of metal-HA complexes, so the high solubility of HA in aqueous media is a limiting problem for taking advantage of the interaction ability of HA (as a solid phase) with metal ions. Accordingly, it is not advisable to use untreated $\mathrm{HA}$ as a sorbent in aqueous media, so an appropriate treatment of $\mathrm{HA}$ is needed [20].

Considering the high binding ability of HA for metal cations, it is interesting to immobilize of humic acid to obtain an insoluble humic-like sorbent [21]. Several approaches for immobilization of $\mathrm{HA}$ have been suggested [22-26]. Unfortunately, these immobilization methods gave an implication on reducing the most active sorption site of HA because of reducing the number of carboxylic group as the most active sorption site during immobilization process.

In the previous report [27-28], we have presented the achievement of our research in synthesizing a high sorption capacity sorbent through the immobilization of $\mathrm{HA}$ on chitosan using glutaraldehyde as a cross-linking agent. Although the sorption capacities of this sorbent toward $\mathrm{Pb}(\mathrm{II}), \mathrm{Cd}(\mathrm{II})$ and $\mathrm{Cr}(\mathrm{III})$ are very high, but the $\mathrm{HA}$ start to be soluble in neutral aqueous medium at the second regeneration [29]. This poor stability of HA in this sorbent showed that attachment of HA on chitosan is not strong enough due to the low stability of hemiacetal or acetal form (product of reaction between aldehyde groups of glutaraldehyde with hydroxyl groups of HA). Based on this result, it was interesting to use another cross-linking agent that can react chemically with HA and chitosan to form a stable product without reducing the active sorption sites of HA.

Recently, we have reported that epichlorohydrin $(\mathrm{ECH})$ can be used as a cross-linking agent to immobilize covalently HA onto chitosan [30]. A stable attachment of HA onto chitosan can occur because $\mathrm{ECH}$ has a chloride and an epoxide group that can react with hydroxyl groups to produce an ether product. As we know that ether is more stable than acetal or hemiacetal. However, although utilization of $\mathrm{ECH}$ as cross-linking agent can produce a stable attachment between HA and chitosan, the yield of activation of $\mathrm{HA}$ by $\mathrm{ECH}$ was very low. On the other side, it was difficult to activate chitosan selectively using $\mathrm{ECH}$ because the high reactivity of the chloride and epoxide groups that can react with hydroxyl or amine groups of chitosan led to form a cross-linking product between chitosan molecules itself. Therefore, it is necessary to use another method to activate chitosan without tendency to form a cross-linking product between chitosan molecules itself.

One of the better activated-chitosan is a tosylchitosan that can be prepared by the reaction of phthaloylated-chitosan with tosyl chloride [31]. The good leaving character of the tosyl group makes tosylatedchitosan useful as an active intermediate for further reactions to yield chitosan derivatives [31]. Jančiauskaitè and Makuška [32] reported a synthesis of chitosan-odextran graft copolymers through activation of primary hydroxyl groups of phthaloylated-chitosan using tosylation method. Synthesis of chitosan-O-alginate copolymers by attaching alginate onto chitosan was also can be performed by activation of primary hydroxyl groups of phthaloylated-chitosan using tosylation method [33]. Because tosyl is a very good leaving group and can be substituted easily by hydroxyl groups, while HA and chitosan have hydroxyl groups in large amount in their structure, it is interesting to examine the immobilization of HA onto chitosan using tosylation method.

However, if HA is coupled directly to the chitosan as a polymeric support, steric hindrance between the support surface and the HA will be occur because both $\mathrm{HA}$ and chitosan are a bulky macromolecules. Another result [34] has shown that employment of spacer arm could set the enzyme away from the solid support and overcome the steric hindrance effect. On immobilization of $\mathrm{HA}$ onto chitosan using glutaraldehyde or $\mathrm{ECH}$ as a cross-linking agent as previously reported [27-30], the products would contained a spacer arm, but if HA was immobilized directly onto a tosyl-chitosan, the product would not contained a spacer arm. For this reason, beside the activation of chitosan with a tosyl group, HA molecules should be moved away from the support surface to some extent using a spacer-arm.

In this work, 1,4-butanediol was used as spacer arm. The 1,4-butanediol was chosen as a spacer arm because of the high reactivity of tosyl group with hydroxyl group of primary alcohols. Based on the success of covalent immobilization of HA onto chitosan using ECH as cross-linking agent [30] and the success of immobilization of sodium alginate on tosyl-chitosan [33], the 1,4-butanediol that has a 4-carbon length will be long enough to overcome the steric hindrance. Here, we report the preparation of covalently immobilized HA-chitosan using tosylation method with 1,4-butanediol as a spacer arm. As a comparison, immobilization of HA onto chitosan was also carried out without spacer arm. To the best of our knowledge, this is the first example for immobilization of $\mathrm{HA}$ onto chitosan using tosylation method. The product was characterized using XRD and FTIR spectrophotometric method.

\section{EXPERIMENTAL SECTION}

\section{Sampling and Sample Preparation}

Sample of peat soil as source of HA was taken in Gambut District of South Kalimantan, Indonesia. Peat soil was air-dried in room condition. Sample of 
crustacean shell waste as a source of chitosan was collected from traditional market in Banjarbaru, South Kalimantan, Indonesia. The crustacean shell was dried under sun light and then crushed and sieved to the size of 80 mesh.

\section{Materials}

$N, N$-dimethyl formamide (DMF), phthalic anhydride, N,N-dimethyl acetamide (DMAc), lithium chloride, tosyl chloride, and triethyl amine (TEA) were obtained from Merck (Germany). All reagents and solvents were of analytical grade and used without further purification.

\section{Instrumentation}

Characterizations of products were conducted using spectrophotometer FTIR (IR Shimadzu 8201-PC) and diffractometer XRD (Shimadzu XRD-6000).

\section{Procedure}

\section{Extraction of humic acid and chitin}

HA was extracted from the peat soil sample according to the procedure of IHSS (International Humic Substances Society) with some modification [35]. Chitin was isolated through deproteination and followed by demineralization processes, and the obtained chitin was transformed to chitosan by common deacetylation method according to the method of No \& Meyer [36].

\section{Preparation of 6-O-tosyl-N-phthaloyl chitosan}

The preparation and FTIR characterization of $N$ phthaloyl-chitosan were done according to the procedure described elsewhere [37]. The preparation and FTIR characterization of 6-O-tosyl- $N$-phthaloyl-chitosan were carried out according to the method reported elsewhere using $N$-phthaloyl-chitosan as raw material [38]. In addition on the FTIR analysis previously reported [37-38], these products were characterized using X-Ray Diffractometer.

\section{Preparation of 6-O-butanol-N-phthaloyl-chitosan}

To a solution of 6-O-tosyl- $N$-phthaloyl-chitosan $(2.52 \mathrm{~g})$ in DMF (100 $\mathrm{mL})$ was added slowly 1,4butanediol $(5 \mathrm{~mL})$ in aqueous $\mathrm{NaOH}$ solution $0.05 \mathrm{~mol} / \mathrm{L}$ $(50 \mathrm{~mL})$ over a $24 \mathrm{~h}$ period at $50{ }^{\circ} \mathrm{C}$. The resulted mixture was cooled at room temperature and poured into ice water. The precipitate obtained by pouring the solution into ice water was collected by filtration, washed with distilled water, and dried to give the product (6-Obutanol- $N$-phthaloyl-chitosan). The product was characterized by recording the FTIR spectrum.

\section{Preparation of 6-O-tosylbutane-N-phthaloyl- chitosan}

Triethylamine $(9.5 \mathrm{~mL}, 68 \mathrm{mmol})$ and toluene-4sulfonyl chloride $(3.6 \mathrm{~g}, 18.8 \mathrm{mmol})$ dissolved in $20 \mathrm{~mL}$ DMAc were gradually added to a cooled solution $\left(4-8{ }^{\circ} \mathrm{C}\right)$ of 6-O-butanol- $\mathrm{N}$-phthaloyl-chitosan $(0.5 \mathrm{~g}$, $1.88 \mathrm{mmol})$ in $\mathrm{DMAc} / \mathrm{LiCl}(50 \mathrm{~mL})$, and the mixture was stirred at $8{ }^{\circ} \mathrm{C}$ for $12 \mathrm{~h}$. The precipitate obtained by pouring the solution into ice water was collected by filtration, washed with chloroform, and dried to give the product (6-O-tosylbutane- $\mathrm{N}$-phthaloyl-chitosan). The product was characterized by recording the FTIR spectrum.

\section{Immobilization of HA on chitosan with and without spacer arm}

Immobilization of HA on chitosan with spacer arm was performed by reacting 6-O-tosylbutane- $N$-phthaloyl chitosan with $\mathrm{HA}$ as described following here. 6-Otosylbutane- $N$-phthaloyl chitosan $(0.30 \mathrm{~g})$ and $\mathrm{NaOH}$ $(0.23 \mathrm{~g})$ were dissolved in DMAc/LiCl $(100 \mathrm{~mL})$. The HA $(0.30 \mathrm{~g})$ was dissolved in DMF $(30 \mathrm{~mL})$, and the resulted solution was added slowly to the solution of 6$O$-tosylbutane- $N$-phthaloyl chitosan. The reaction between 6-O-tosylbutane- $N$-phthaloyl chitosan and HA was carried out for $48 \mathrm{~h}$ at $50{ }^{\circ} \mathrm{C}$ under stirring. The resulting dark brown mixture was cooled to room temperature and poured into ice water. The dark brown precipitate was collected on a filter, washed with chloroform and distilled water, and dried to give the product as a pale tan powdery material. The product was characterized by recording the FTIR spectrum.

Immobilization of HA on chitosan without spacer arm was done by reacting 6-O-tosyl- $N$-phthaloyl chitosan with $\mathrm{HA}$ as described in the procedure for Immobilization of HA on chitosan 6-O-tosylbutane- $\mathrm{N}$ phthaloyl chitosan. The resulting dark brown mixture was cooled to room temperature and poured into ice water, but there was no appreciable brown or pale brown precipitate can be obtained.

\section{Deprotection of phthaloyl groups}

In order to remove the protecting phthaloyl groups, $1.3 \mathrm{~g}$ of immobilized HA-6-O-butane-Nphthaloyl chitosan was spread in $130 \mathrm{~mL}$ of DMF, and $13 \mathrm{~mL}$ of hydrazine monohydrate was added dropwise. The reaction mixture was stirred for $2 \mathrm{~h}$ at $80^{\circ} \mathrm{C}$, and the resulting solution containing a target copolymer was filtered, washed with distilled water, and dried. The product was characterized by recording the XRD and FTIR spectrum. 


\section{RESULT AND DISCUSSION}

Immobilization of $\mathrm{HA}$ onto chitosan using tosylation method has been evaluated with and without 1,4-butanediol as a spacer arm. Immobilization of HA on chitosan using spacer arm was carried out with several steps (Fig. 1). First step is phthaloylation chitosan by reacting chitosan with phthalic anhydride in dimethylformamide as solvent with addition of $5 \%$ water $(\mathrm{v} / \mathrm{v})$ as cosolvent. Second step is tosylation of $\mathrm{N}$-phthaloyl-chitosan with excess tosyl chloride in $\mathrm{DMAc/LiCl}$ as solvent and triethylamine as catalyst. The third step is attaching 1,4-butanediol as a spacer arm onto 6-O-tosyl- $N$-phthaloyl-chitosan. The fourth is tosylation of the spacer arm attached chitosan. The final step is immobilization of HA onto 6-O-tosylbutane- $\mathrm{N}$ phthaloyl-chitosan. For immobilization of HA onto chitosan without spacer arm was performed by reacting directly HA with 6-O-tosyl- $N$-phthaloyl-chitosan.

\section{Phthaloylated- and Tosylated-Chitosan}

Beside functional groups analysis using Infrared spectrophotometric method, characterization of the products of phthaloylation and tosylation of chitosan using XRD crystallography method was also performed in order to study on the effect of these treatments on its crystallinity. Fig. 2 showed the XRD pattern of 6-O-tosyl$\mathrm{N}$-phthaloyl-chitosan as compared with that $\mathrm{N}$-phthaloylchitosan and chitosan.

The original chitosan (Fig. 2) showed two major crystalline peaks at $2 \theta=10.5^{\circ}$ and $20.1^{\circ}$, which were in good agreement with earlier published data [39]. The previously result [40] reported that chitosan has two distinct crystal forms I and II. The form I crystal is orthorhombic having a unit cell of $a=7.76 \AA, b=10.91$ $\AA$, and $c=10.30 \AA$. The strongest reflection falls at $2 \theta=$ $11.5^{\circ}$, which is assigned to (100) reflection. The form II crystal is also orthorhombic having an unit cell of $a=4.4$ $\AA, b=10.0 \AA$, and $c=10.3 \AA$ (fiber axis). The strongest reflection appears at $2 \theta=20.2^{\circ}$, which also corresponds to the (100) reflection. Therefore, Fig. 2 showed that the original chitosan contained dominantly a crystal in the form II.

Fig. 2 showed that $\mathrm{N}$-phthaloyl-chitosan is more crystalline than the original chitosan. $\mathrm{N}$-phthaloyl chitosan showed four major peaks at around $2 \theta=7.0^{\circ}$, $12.4^{\circ}, 19.2^{\circ}$, and $26.7^{\circ}$, which were in good agreement with earlier published data [41]. Kurita et al. [41] have shown that the phthaloylated product prepared in DMF (without addition of $5 \%$ water as cosolvent) showed one broad peak at around $2 \theta=20^{\circ}$ together with only one weak peak at around $2 \theta=7^{\circ}$, suggesting that partial Osubstitution in addition to the $\mathrm{N}$-substitution cause the chitosan derivative appeared amorphous. Appearance of
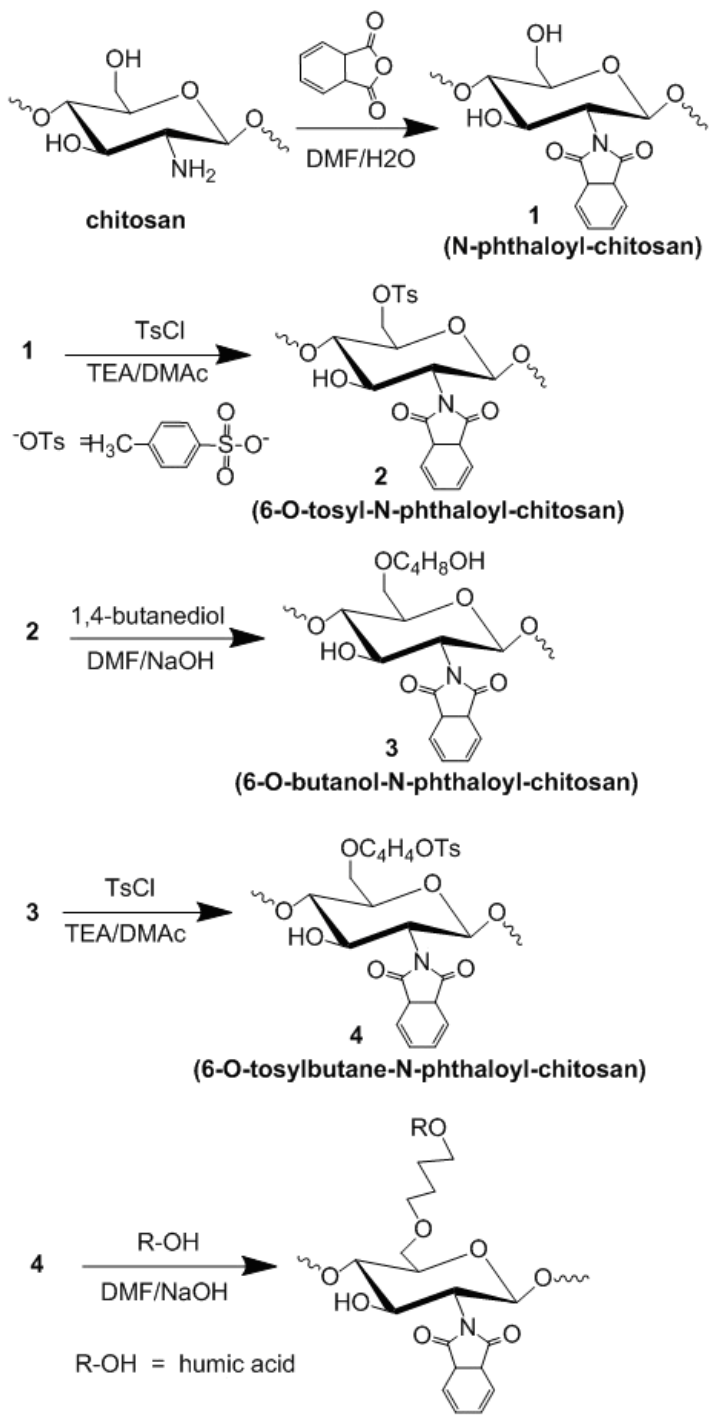

Fig 1. Schematic representation of immobilization of HA on chitosan using tosylation method with 1,4butanediol as a spacer arm

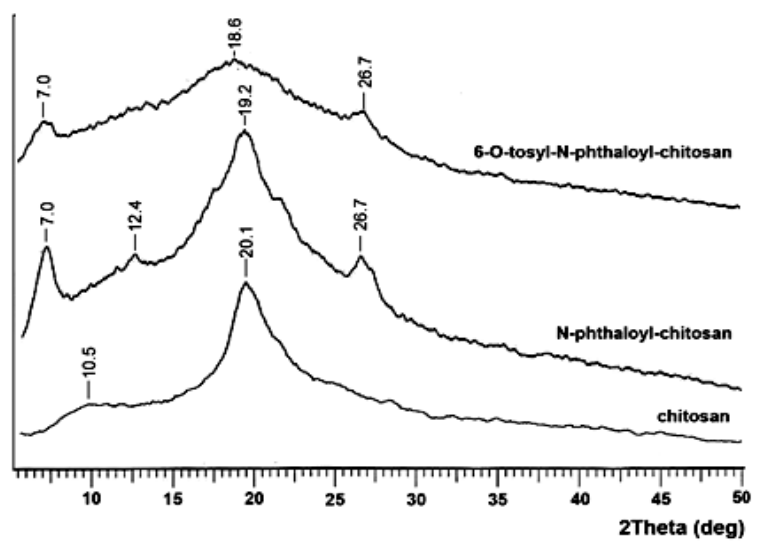

Fig 2. XRD pattern of chitosan (bottom), N-phthaloylchitosan (middle), and 6-O-tosyl- $\mathrm{N}$-phthaloyl-chitosan (top) 
four peaks in XRD pattern of the N-phthaloyl-chitosan suggested that the phthaloylation reaction was occurred selectively at $\mathrm{N}$-atom only.

At the contrary, XRD pattern in Fig. 2 showed that 6 -O-tosyl- $\mathrm{N}$-phthaloyl-chitosan is less crystalline than $\mathrm{N}$ phthaloyl-chitosan. The XRD profile of 6-O-tosyl- $N$ phthaloyl-chitosan showed one broad peak at around $2 \theta=20.0^{\circ}$ together with two weak peaks at around $2 \theta=7.0^{\circ}$ and $2 \theta=26.7^{\circ}$, suggesting that O-substitution (by tosyl group) in addition to the $\mathrm{N}$-substitution (by phthaloyl group) cause the chitosan derivative appear amorphous. As a comparison, the partial O-substitution (by phthaloyl group) in addition to the $\mathrm{N}$-substitution (by phthaloyl group) cause the chitosan derivative became amorphous [41]. The disruption of the crystalline structure of $\mathrm{N}$-phthaloyl-chitosan after tosylation treatment can be explained by the loss of the ability of forming hydrogen bonding between chains of chitosan because of the substitution of hydroxyl group in the polysaccharide structures by tosyl group.

FTIR analysis for $\mathrm{N}$-phthaloyl-chitosan and 6-Otosyl-chitosan has been reported in our previous report [29-30]. Here, FTIR spectrum of N-phthaloyl-chitosan and 6-O-tosyl-chitosan was reported as a comparison with the spacer arm attached chitosan (Fig. 3). As shown in Fig. 3, the structures of $\mathrm{N}$-phthaloyl-chitosan was confirmed by the characteristic peaks of phthalimido group $\left(1774,1712 \mathrm{~cm}^{-1}(\mathrm{C}=\mathrm{O}\right.$ anhydride $\left.)\right)$, and aromatic ring $\left(721 \mathrm{~cm}^{-1}\right)$. This product showed no weak bands at $2600-2700 \mathrm{~cm}^{-1}$ (free carboxyl) and sharp ones at 1288 and $1265 \mathrm{~cm}^{-1}$ (ester) in the FTIR spectrum that suggests complete cyclization at the amino group and/or fullness of O-phthaloylation [29]. The FTIR spectrum of 6-O-tosyl-N-phthaloyl chitosan [30] showed a characteristic absorption at $1188 \mathrm{~cm}^{-1}$ due to tosyl groups $\left(\mathrm{SO}_{2}\right)$, absorption at $818 \mathrm{~cm}^{-1}$ was characteristic of C-O-S, $1643 \mathrm{~cm}^{-1}$ was typical of peak of aromatic $\mathrm{C}=\mathrm{C}$ arising from the tosyl group, absorption at 1713 and $1774 \mathrm{~cm}^{-1}$ were characteristic of carbonyl in phthalimide, absorption at about $700 \mathrm{~cm}^{-1}$ was characteristic of aromatic arising from phthaloyl group, and the band at $1389 \mathrm{~cm}^{-1}$ could be attributed to $-\mathrm{CH}_{2}$ bending modes.

\section{Spacer Arm Attached Chitosan and HA Immobilized Chitosan}

A spacer arm was used here in order to prevent or minimize the steric hindrance between the support surface (chitosan) and the HA. The 1,4-butanediol was used as a spacer arm due to the high reactivity of tosyl group with hydroxyl groups of a primary alcohol. After activating the hydroxyl groups at the end of spacer arm molecule, it was expectable that tosyl group of spacer arm attached chitosan can be replaced by hydroxyl groups of HA.

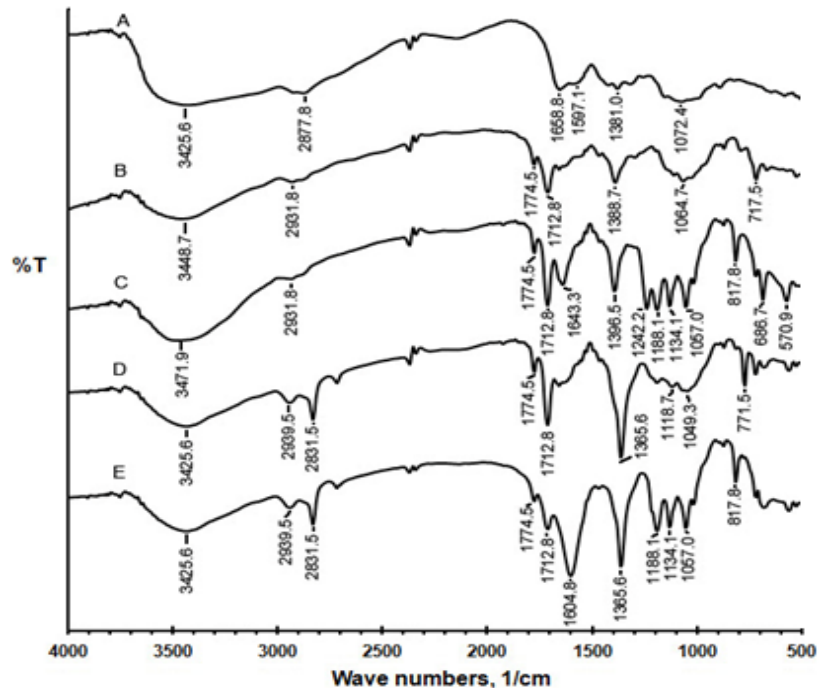

Fig 3. The FTIR spectra of spacer arm attached chitosan before (D) and after (E) activating with tosylchloride in comparison with 6-O-tosyl- $N$-phthaloylchitosan (C), N-phthaloyl-chitosan (B), and chitosan (A)

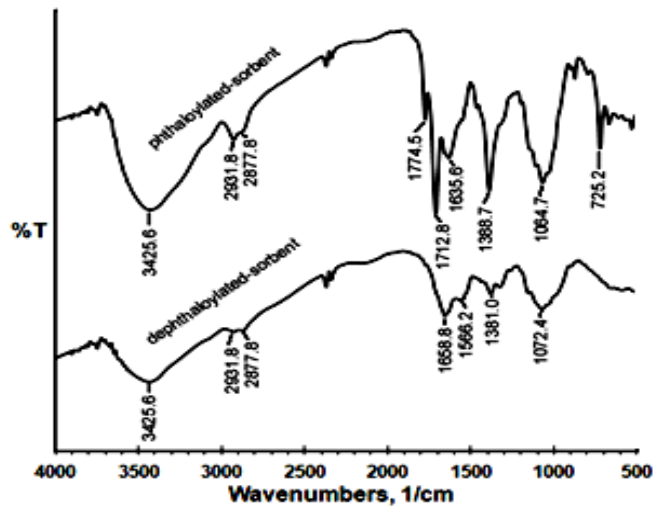

Fig 4. The FTIR spectra of HA immobilized on spacer arm attached chitosan before (top) and after (bottom) dephthaloylation treatment

As mentioned in procedure section, reaction of HA with 6-O-tosyl-N-phthaloyl chitosan did not give a brown or pale brown product. It indicated that HA cannot be immobilized directly onto a tosylatedchitosan without spacer arm due to steric hindrance. Fortunately, tosyl-HA can be reacted covalently with a spacer arm attached chitosan, as indicated by obtained a dark brown precipitate.

FTIR spectra of spacer arm attached chitosan before and after activating with tosyl chloride in comparison with 6-O-tosyl- $N$-phthaloyl-chitosan, $\mathrm{N}$-phthaloyl-chitosan, and chitosan was shown in Fig. 3. FTIR spectra of the spacer arm attached chitosan before being activated by tosyl chloride was shown in Fig. 3D. This product resulted remarkable modification on the FTIR spectrum of 6-O-tosyl- $N$-phthaloylchitosan. The intensity of peaks at about $2800 \mathrm{~cm}^{-1}$ 
(C-H stretch vibrations of $-\mathrm{CH}_{2}$ - aliphatic) and $1380 \mathrm{~cm}^{-1}$ $\left(\mathrm{CH}_{2}\right.$ deformation vibration) after reacting with 1,4butanediol is more intense than before. Increasing the intensity of absorption band of the $\mathrm{C}-\mathrm{H}$ stretch vibrations indicated the success of introducing of 1,4-butanediol. The FTIR spectrum of 6-O-tosyl- $N$-phthaloyl chitosan after reacting with 1,4-butanediol showed no characteristic absorptions at about $1180 \mathrm{~cm}^{-1}\left(\mathrm{SO}_{2}\right)$, $800 \mathrm{~cm}^{-1}$ (C-O-S), and $1600 \mathrm{~cm}^{-1}$ (aromatic $\mathrm{C}=\mathrm{C}$ arising from the tosyl group). The disappearances of these characteristic absorption band of tosyl group indicate that tosyl groups was displaced by the hydroxyl group of 1,4-butanediol, confirming the formation a covalent bond between spacer arm molecule with 1,4-butanediol. Therefore, it can be assumed that the product with structure of a 6-O-butanol- $N$-phthaloyl-chitosan has been formed.

At the contrary, the characteristic peaks of tosyl group at $1180 \mathrm{~cm}^{-1}, 800 \mathrm{~cm}^{-1}$, and $1600 \mathrm{~cm}^{-1}$ of $6-0-$ butanol- $N$-phthaloyl-chitosan after reacting with tosyl chloride (Fig. 3E) appeared again. The appearance of these peaks confirmed that the spacer arm attached chitosan has been activated by introducing tosyl groups.

Based on the success of preparing the activated support, 6-O-tosylbutane- $N$-phthaloyl-chitosan, it was interesting to examination on the immobilization of HA onto the support. In order to remove the phthaloyl groups that blocked the amino groups of chitosan, the phthaloyl groups were removed using hydrazine monohydrate. FTIR spectra of HA immobilized onto 6-Otosylbutane- $N$-phthaloyl-chitosan before and after dephthaloylation reaction was shown in Fig. 4. The disappearance of the absorption peaks at 1774 , $1712 \mathrm{~cm}^{-1}$ and $721 \mathrm{~cm}^{-1}$ indicated the success of dephthaloylation reaction.

Fig. 5 showed the change in the XRD pattern of dephthaloylation treatment of sorbent produced through reaction of 6-O-tosylbutane- $N$-phthaloylchitosan. Before dephthaloylation treatment, the sorbent showed a broad reflection at around $2 \theta=19.0^{\circ}$ together with a reflection at $2 \theta=6.2^{\circ}$ and $2 \theta=26.7^{\circ}$. The increasing of intensities of these reflections compared with the intensities of 6-Otosyl- $N$-phthaloyl-chitosan reflections (Fig. 2) indicated that the main polysaccharide chains can keep a-axis $(100)$ reflection after attachment and activation of spacer 1,4-butanediol which prevailed in the 6-O-tosyl- $N$ phthaloyl-chitosan structures. The shifting of reflection from $2 \theta=7.0^{\circ}$ in the 6-O-tosyl- $N$-phthaloyl-chitosan to $2 \theta=6.2^{\circ}$ in the sorbent indicated an increasing in $d$ spacing of this reflection. Zong et al. [40] have reported that acylation of chitosan by reacting chitosan with hexanoyl, decanoyl, and lauroyl chlorides cause the polymers formed a layered structure in solid state and the layer spacing $d$ increases linearly with increasing the length of side chains.

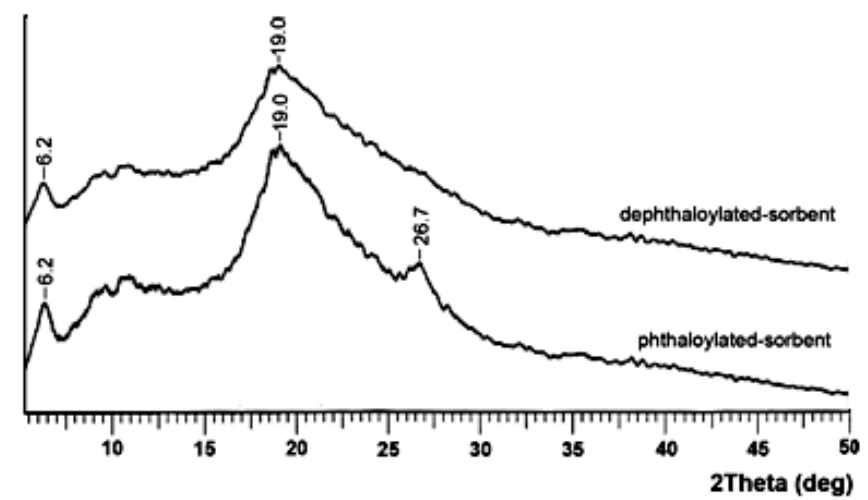

Fig 5. XRD pattern of sorbent produced through reaction of 6-O-tosylbutane- $N$-phthaloyl-chitosan with humic acid before (bottom) and after (top) dephthaloylation treatment

Furthermore, Fig. 5 also showed that the intensities of peaks of sorbent after dephthaloylation treatment decreased and a peak at $2 \theta=26.7^{\circ}$ disappeared, indicating the loss of phthaloyl groups and some structure disruption of the sorbent become more amorphous. Because loss of phthaloyl groups regenerated the free of amino groups of chitosan, some reaction between carboxylic groups of HA and with these free amino groups of chitosan probably occurred randomly and some structure disruption occurred.

A qualitative solubility test indicated that the HA immobilized on chitosan, with and without dephthaloylation treatment, were insoluble in distilled water at $\mathrm{pH} 2,4,6,8,10$, and 12. It indicated that HA was immobilized covalently onto chitosan. However, disappearance of absorption peak at about $1700 \mathrm{~cm}^{-1}$ after dephthaloylation treatment indicated that carboxylic groups of HA may be reacted with amine groups of chitosan or with amine groups of hydrazine. The appearance of absorption peak at $1659 \mathrm{~cm}^{-1}$ (amide) after dephthaloylation treatment suggested that carboxylic group of HA was reacted with amine group to form an amide linkage. On the context of utilization of $\mathrm{HA}$ as sorbent of heavy metals, it is necessary to keep the carboxylic groups remain free. Based on the spectra as shown in Fig. 4, therefore, it is probable that the sorbent produced by reacting of HA onto 6-Otosylbutane- $N$-phthaloyl-chitosan without dephthaloyla tion treatment is better than that sorbent with dephthaloylation treatment.

\section{CONCLUSION}

The present work demonstrated that HA can be immobilized covalently onto chitosan by tosylation method using 1,4-butanediol as a spacer arm. The obtained products by this method with and without 
dephthaloylation treatment were insoluble in acidic and basic aqueous medium. Based on the FTIR spectra, the product of immobilization of HA onto 6-O-tosylbutane- $N$ phthaloyl-chitosan without dephthaloylation treatment is more probable used as sorbent than that product with dephthaloylation treatment.

\section{ACKNOWLEDGEMENT}

The authors would like to thank to Directorate of Research and Community Services, Directorate General of Higher Education (DIKTI), Department of National Education of Indonesia, for financial support of this research (Penelitian Hibah Bersaing with contract number: 008/SP2H/PL/Dit.Litabmas/IV/2011).

\section{REFERENCES}

1. de la Rosa, G., Peralta-Videa, J.R., and GardeaTorresdey, J.L.., 2003, J. Hazard. Mater., B97, 207-218.

2. Barančíková, G., and Makovníková, J., 2003, Plant Soil Environ., 49, 565-571.

3. Martyniuk, H., and Wieckowska, J., 2003, Fuel Process. Technol., 84, 1-3, 23-36.

4. Prado, A.G.S., and Airoldi, C., 2003, Thermochim. Acta, 405, 287-292.

5. Baek, K., and Yang, J.W., 2005, Sep. Sci. Technol., 40, 699-708.

6. Klučáková, M., and Pekar, M., 2006, Colloids Surf., A, 286, 126-133.

7. Buhani and Suharso, 2006, Indo. J. Chem., 6, 1, 43-46.

8. Bianchi, V., Masciandaro, G., Giraldi, D., Ceccanti, B., and lannelli, R., 2008, Water Air Soil Pollut., 193, 1-4, 323-333.

9. Furukawa, K., and Takahashi, Y., 2008, Chemosphere, 73, 8, 1272-1278.

10. Al-Faqih, L., Johnson, P.D., and Allen, S.J., 2008, Bioresour. Technol., 99, 5, 1394-1402.

11. Sedláček, P., and Klučáková, M., 2009, Geoderma, 153, 11-17.

12. Havelcova, M., Mizera, J., Sykorova, I., and Pekar, M., 2009, J. Hazard. Mater., 161, 1, 559-564.

13. Anđelković, T., Perović, J., Blagojević, S., Purenović, M., Nikolić, R., Bojić, A., and Anđelković, D., 2006, Bull. Chem. Technol. Maced., 25, 2, 131-137.

14. Vinkler, P., Lakatos, B., and Meisel, J., 1976, Geoderma, 15, 3, 231-242.

15. Piccolo, G.A., and Stevenson, F.J., 1982, Geoderma, 27, 3, 195-208.

16. Fukushima, M., Nakayasu, K., Tanaka, S., and Nakamura, H., 1995, Anal. Chim. Acta, 317, 1, 195-206.
17. Evangelou, V.P., Marsi, M., and Chappell, M.A., 2002, Spectrochim. Acta, Part A, 58, 2159-2175.

18. Terckhi, M.C., Taleb, F., Gossart, P., Semmoud, A., and Addou, A., 2008, J. Photochem. Photobiol., A, 198, 2-3, 205-214.

19. Aiken, G.R., McKnight, D.M., Wershaw, R.L., and McCarthy, P., 1985, An introduction to humic substances in soils, sediments and waters, in: G.R. Aiken, D.M. McKnight, R.L. Wershaw, P. McCarthy (Eds.), Humic Substances in Soil, Sediment, and Water: Geochemistry, Isolation and Characterization, John Wiley and Sons, New York, 1-9.

20. Gezici, O., Kara, H., Ersöz, M., and Abali, Y., 2005, J. Colloid Interface Sci., 292, 2, 381-391.

21. Santosa, S.J., Tanaka, S., Siswanta, D., Kunarti, E.S., Sudiono, S., and Rahmanto, W.H., 2007, Indonesian Peat Soil Derived Humic Acid: Its Characterization, Immobilization, and Performance as Metal Sorbent, Proceeding of International Conference on Chemical Sciences (ICCS-2007), Yogyakarta, Indonesia, 1-6.

22. Irawati, U., Santosa, S.J., Sudiono, S., 2005, Imobilization of Humic Acid on Chitosan and Its Application as Sorbent of $\mathrm{Cd}(\mathrm{II})$, Proceeding of International Seminar on Environmental Chemistry and Toxicology (2 $2^{\text {nd }}$ InSECT), Yogyakarta, Indonesia, 129-134.

23. Santosa, S.J., Sundari, S., and Sudiono, S., 2006, e-J. Surf. Sci. Nanotechnol., 4, 46-52.

24. Santosa, S.J., Sudiono, S., and Sujandi, S., 2006, e-J. Surf. Sci. Nanotechnol., 4, 602-608.

25. Santosa, S.J., Siswanta, D., Sudiono, S., and Sehol, M., 2007, Surf. Sci., 601, 5148-5154.

26. Santosa, S.J., Siswanta, D., Sudiono, S., and Utarianingrum, R., 2008, Appl. Surf. Sci., 254, 23, 7846-7850.

27. Santoso, U.T., Irawati, U., Umaningrum, D., and Nurmasari, R., 2008, Indo. J. Chem., 8, 2, 177-183.

28. Santoso, U.T., Irawati, U., Umaningrum, D., Nurmasari, R., Santosa, S.J., Siswanta, D., Rusdiarso, B., 2009, Improvement of Degree of Active Sites Deprotection for Enhancing the Ability of Crosslinked Humic Acid-Chitosan as Sorbent for $\mathrm{Pb}(\mathrm{II})$, Proceeding of International Seminar on Sciences and Technology (ISSTEC), Yogyakarta, Indonesia, 706-712.

29. Santoso, U.T., Santosa, S.J., Rusdiarso, B., Siswanta, D, and 2010, Indo. J. Chem., 10, 3, 301-309.

30. Santoso, U.T., Santosa, S.J., Siswanta, D., Rusdiarso, B., and, Shimazu, S., 2010, Evaluation of humic acid activation with epichlorohydrin and its interaction with chitosan, Proceeding of The $2^{\text {nd }}$ 
International Conference on Chemical Sciences $\left(2^{\text {nd }}\right.$ ICCS), Yogyakarta, Indonesia, 41-44.

31. Nishimura, S., Kohgo, O., Kurita, K., and Kuzuhara, H., 1991, Macromolecules, 24, 17, 4745-4748.

32. Jančiauskaitè, U., and Makuška, R., 2008, Chemija, 19, 2, 35-42.

33. Jančiauskaitè, U., Višnevskij, C., Radzevičius, K., and Makuška, R., 2009, Chemija, 20, 2, 128-135.

34. Arıca, M.Y., Altıntas, B., and Bayramoglu, G., 2009, Bioresour. Technol., 100, 2, 665-669.

35. Santoso, U.T., and Herdiansyah, 2004, Indo. J. Chem., 4, 1, 12-25.

36. No, H.K., and Meyer, S.P., 1989, J. Agric. Food Chem., 37, 3, 580-583.

37. Nurmasari, R., Santoso, U.T., and Umaningrum, D., 2011, A Novel Process to Prepare Chemoselectively Protected N-Phthaloyl-Chitosan without Drying of Solvent and Purging of Water Vapor, Proceeding of
International Conference on Bioscience and Biotechnology (ICBB 2011), Yogyakarta, Indonesia.

38. Santoso, U.T., Nurmasari, R., and Umaningrum, D., 2011, Tosylation of N-Phthaloyl-Chitosan without Drying of Solvents and Purging of Water Vapor, Proceeding of International Conference on Bioscience and Biotechnology (ICBB 2011), Yogyakarta, Indonesia.

39. Gorochovceva, N., Kulbokaitë, R., Juðkënas, R., and Makuška, R., 2004, Chemija, 15, 1, 22-27.

40. Zong, Z., Kimura, Y., Takahashi, M., and Yamane, H., 2000, Polymer, 41, 3, 899-906.

41. Kurita, K., Ikeda, H., Yoshida, Y., Shimojoh, M., and Harata, M., 2002, Biomacromolecules, 3, 1, $1-4$. 